\title{
ВИКОРИСТАННЯ МОРКВЯНИХ ПОРОШКІВ ДЛЯ ЗБАГАЧЕННЯ МОЛОКА МІНЕРАЛЬНИМИ ЕЛЕМЕНТАМИ
}

\author{
М. М. САМІЛИК, кандидат технічних наук, доцент \\ (Сумський національний аграрний університет); \\ Р. В. ЦИРУЛИК (Сумський національний аграрний університет)
}

\begin{abstract}
Анотація. Молоко є основним джерелом білків і обов'язковим продуктом у щзоденному харчовому раціоні дітей. Рекомендується вживати молоко, до якого додано вітаміни та мінеральні речовини. Саме тому збагачення молока є актуальним питанням. Мета дослідження - обтрунтування доцільності використання морквяних порошків для збагачення молока мінеральними речовинами. Показники якості молока визначалися за стандартними методиками: органолептична очінка проведена за ДСТУ 2661:2010, титрована кислотність визначалася за ДСТУ 8550:2015. Хімічний аналіз порошків проведено методом електронної мікроскопї з використанням детекторів SEM ma EDS. Із коренеплодів моркви сорту Шантане та їхніх шкірок у лабораторних умовах було виготовлено порошки та розроблено технологію збагачення ними молока А2. Аналіз хімічного складу показав, що морквяні порошки з основної частини коренеплодів містять K (27,1\%), Ca (6,97\%), Cl (5,09\%), P (3,82\%), $\mathrm{Na}$ (3,3\%), Fe (1,07\%), $\mathrm{Mg}(0,75 \%)$ i S (0,47\%). Встановлено, щзо додавання порошку із коренеплодів моркви у кількості $10 \%$ позитивно вплинуло на органолептичні властивості молока, не знижуючи його здатності до зберігання. Збагачене молоко мало характерний пастеризованому запах, приємний кремовий колір і легкий присмак моркви. Консистенція розробленого продукту відповідала консистенції пастеризованого молока. Виявлено, шчо у порошках із морквяних шкірок деяких мінеральних речовин міститься більше, ніж у основній частині коренеплоду: $\mathrm{K}$ - на 4,28\%, $\mathrm{Fe}-\mathrm{Ha}$ 0,73\%, $P$ - на 0,45\%, $S-$ на 0,12\%, але додавання таких порошків до молока значно знижує його якісні показники та призводить до швидкого псування продукту. Зразок із порошком із морквяних відходів мав бруднуватий відтінок і характерний овочевий присмак і аромат. Кислотність молока із додаванням порошку із морквяних шкірок перевищувала на $4^{\circ}$ Т нормативну. Така технологія може бути безвідходною, у разі висушування морквяної мезги, отриманої після фільтрування молока, і використання ї̈ як харчової добавки. Розробка технологї̈ використання висушеної морквяної мезги є перспективою подальших досліджень.
\end{abstract}

Ключові слова: збагачене молоко А2, морквяний порошок, морквяні шкірки, хімічний склад, мінеральні речовини, безвідходна технологія.

Постановка проблеми у загальному вигляді. Відповідно до Норм харчування у закладах освіти та дитячих закладах оздоровлення та відпочинку [1] молоко та молочні продукти є основним джерелом білків і є обов'язковими у щоденному дитячому раціоні. Рекомендовано споживати молоко i молочні продукти, до яких додано вітаміни та мінеральні речовини. Такі добавки надають молочним продуктам додаткові функціональні властивості, проте асортимент збагаченого молока на ринку України представлено лише декількома виробниками.

На відміну від звичайних, молочні продукти функціонального призначення, крім високої харчової цінності та гарного смаку, повинні позитивно впливати на здоров'я людини [2]. Особливої уваги потребує харчовий раціон дітей. Відомо, що діти мають підвищений (у 1,5-2 рази) основний обмін порівняно з дорослими, тому під час розробки харчових раціонів для дітей слід звертати особливу увагу на продукти 3 високим рівнем білків та інших нутрієнтів. Білки є основним пластичним матеріалом, із якого будуються нові клітини та тканини [3]. Особливе значення серед білковмісних продуктів має молоко.

(C) Самілик М. М., Цирулик Р. В., 2021
Основним білком молока $є \beta$-казеїн. Існує два типи $\beta$-казеїну: A1 та A2, відмінність яких зумовлена амінокислотною послідовністю. Тип A1 містить гістидин, а тип А2 - пролін у 67 положенні амінокислотної послідовності [4]. При розщепленні $\beta$-казеїну типу A1 утворюється $\beta$-казоморфін - опіоїд, здатний викликати порушення у травній і нервовій системах [5]. Водночас молоко А2 краще засвоюється і має гіпоалергенні властивості [4], тому розробляти збагачене молоко доцільно на основі молока, що містить лише $\beta$-казеїн типу А2.

Обов'язковими нутрієнтами у харчуванні є вітаміни [6]. Вони регулюють безліч фізіологічних процесів, включаючи метаболізм вуглеводів, білків, жирів, засвоєння кисню, гемоглобіну, i є основою фізичної працездатності. Збагачені вітамінами молочні продукти можна застосовувати як лікувальні засоби за вітамінної недостатності, а також для підвищення захисних функцій організму [7].

Аналіз останніх досліджень і публікацій. Існує декілька технологій збагачення молока. Апробовано у промислових умовах технологію виробництва молока, збагаченого вітамінами $\mathrm{A} \mathrm{i} \mathrm{D}_{2}, \mathrm{C}$, доведено його придатність для масового 
виробництва [8]. Відомий спосіб отримання молока i молочних продуктів, що передбачає введення перед пастеризацією або стерилізацією розчиненого у невеликій кількості йодистого субстрату [9]. Розроблена і застосовується у виробництві технологія ультрапастеризованого молока, збагаченого йодом [10].

Запропоновано технологію пастеризованого молока 3 додаванням ванільну і вітамінів. Як добавка для збагачення використаний $\beta$-каротин, отриманий із моркви методом екстрагування в олії [11]. Встановлено, що молоко, збагачене каротиноїдами моркви, має кращу здатність до зберігання. Очевидно, це пов'язано 3 тим, що $\beta$-каротин сповільнює мікробіологічні процеси [12]. У промислових умовах для збагачення молочних продуктів використовуються: вітамінний комплекс FT 041081EU, який містить 12 важливих вітамінів (А, Д, Е, C, Bc, В1, В2, В6, В12, РР, В5, біотин) і комплекс мінеральних речовин FT 042836EU, до складу якого входять $\mathrm{Fe}, \mathrm{Zn}$ та I [13].

Аналіз літератури показав, що наявні технології збагачення молока переважно передбачають використання синтетично створених вітамінно-мінеральних комплексів. Практично відсутні продукти на натуральній основі, хоча доведено, що натуральні вітаміни засвоюється набагато краще, ніж синтетичні [14]. Це пов'язано з тим, що при вживанні натуральних продуктів в організм потрапляють, крім вітамінів і мінеральних речовин, ще й ферменти, які забезпечують їх оптимальне засвоєння. Як природне джерело корисних речовин обрано моркву (Daucus carota). Вона містить велику кількість каротиноїдів [15; 16], 95\% яких становлять каротини. Встановлено, що 35\% каротиноїдів сухої моркви перетворюється у вітамін А [17], тому оптимальною формою для внесення моркви у молоко $є$ порошкова. Каротиноїди стійкі до зміни кислотності та температур, витримують нагрівання (до $130^{\circ} \mathrm{C}$ ). Відомо також, що вони $\epsilon$ антиоксидантами та мають високу біологічну активність [18].

Більшість попередньо проведених досліджень присвячені розробці технологій застосування моркви та морквяних порошків у напрямку збагачення молочних продуктів каротином, проте практично відсутня інформація щодо можливості використання морквяних порошків як джерела мінеральних речовин.

Формування цілей статті. Метою роботи $\epsilon$ обгрунтування доцільності використання морквяних порошків для збагачення молока мінеральними елементами.

На основі поставленої мети сформовано завдання дослідження:

- проаналізувати хімічний них порошків, обгрунтувати доцільність їх застосування для збагачення молока мінеральними речовинами;

- розробити технологічну схему збагачення молока морквяними порошками;

- провести органолептичну оцінку молока, збагаченого морквяними порошками;

- дослідити здатність до зберігання молока, збагаченого морквяними порошками.

Виклад основного матеріалу дослідження. Експериментальні дослідження проведено у лабораторних умовах на кафедрі технологій і безпечності харчових продуктів Сумського національного аграрного університету. Предметом дослідження були порошки, виготовлені 3 моркви сорту Шантане. Об'єкт дослідження - технологія виробництва питного збагаченого молока. Вітаміни та мінеральні речовини можна додавати до харчових продуктів у біодоступній для організму формі, незважаючи на те, чи містяться вони у харчовому продукті [19]. Тому для досліджень виготовлено порошки із моркви та морквяних шкірок. Ретельно відмиті коренеплоди очищували від шкірки, нарізали слайсами (товщиною 2 мм) і висушували за температури $45-50^{\circ} \mathrm{C}$ протягом 3 годин в інфрачервоній лабораторній сушарці потужністю 1,8 кВт. Після висушування матеріал подрібнювали на дисковому млині ЛЗМ-1 і просіювали через латунне сито № 015. Для подальшого дослідження використовували лише фракцію менше 0,15 мм.

3 метою обгрунтування доцільності застосування морквяних порошків для збагачення молока мінеральними елементами було проаналізовано їх хімічний склад. Аналіз проводили за допомогою детектора SEM та EDS на основі мікроскопа SEOSEM Inspect S50-B. Зразки для дослідження запресовували у таблетки діаметром 2 мм зііз шліфованою зовнішньою поверхнею. Результати аналізу представлено на рис. 1, 2.

Аналіз показав, що в основній частині коренеплодів моркви міститься: $27,1 \% \mathrm{~K} ; 6,97 \% \mathrm{Ca}$; $5,09 \% \mathrm{Cl} ; 3,82 \% \mathrm{P} ; 3,3 \% \mathrm{Na} ; 1,07 \% \mathrm{Fe} ; 0,75 \%$ $\mathrm{Mg}$ i $0,47 \%$ S. Вищезазначені макро- та мікроелементи $€$ життєво необхідними для людини.

Також проаналізовано хімічний склад порошків із морквяних шкірок із метою визначення можливості їх використання для виготовлення збагаченого молока.

У шкірці моркви виявлено: $31,38 \%$ К; $2,49 \%$ $\mathrm{Ca} ; 6,32 \% \mathrm{Cl}, 4,27 \% \mathrm{P}, 1,69 \% \mathrm{Na}, 1,8 \% \mathrm{Fe}, 0,32 \%$ $\mathrm{Mg}$ і $0,59 \% \mathrm{~S}$. Встановлено, що деяких елементів у шкірці міститься більше, ніж у основній частині коренеплоду: К - на 4,28\%, $\mathrm{Fe}$ - на $0,73 \%, \mathrm{P}$ - на $0,45 \%, \mathrm{~S}$ - на $0,12 \%$. Тому один зі зразків збагаченого молока було виготовлено на основі порошків із морквяної шкірки. Враховуючи, що на поверхні коренеплодів при їх вирощуванні накопичується найбільша кількість мінералів, доцільно переробляти лише шкірки органічної моркви, під час 


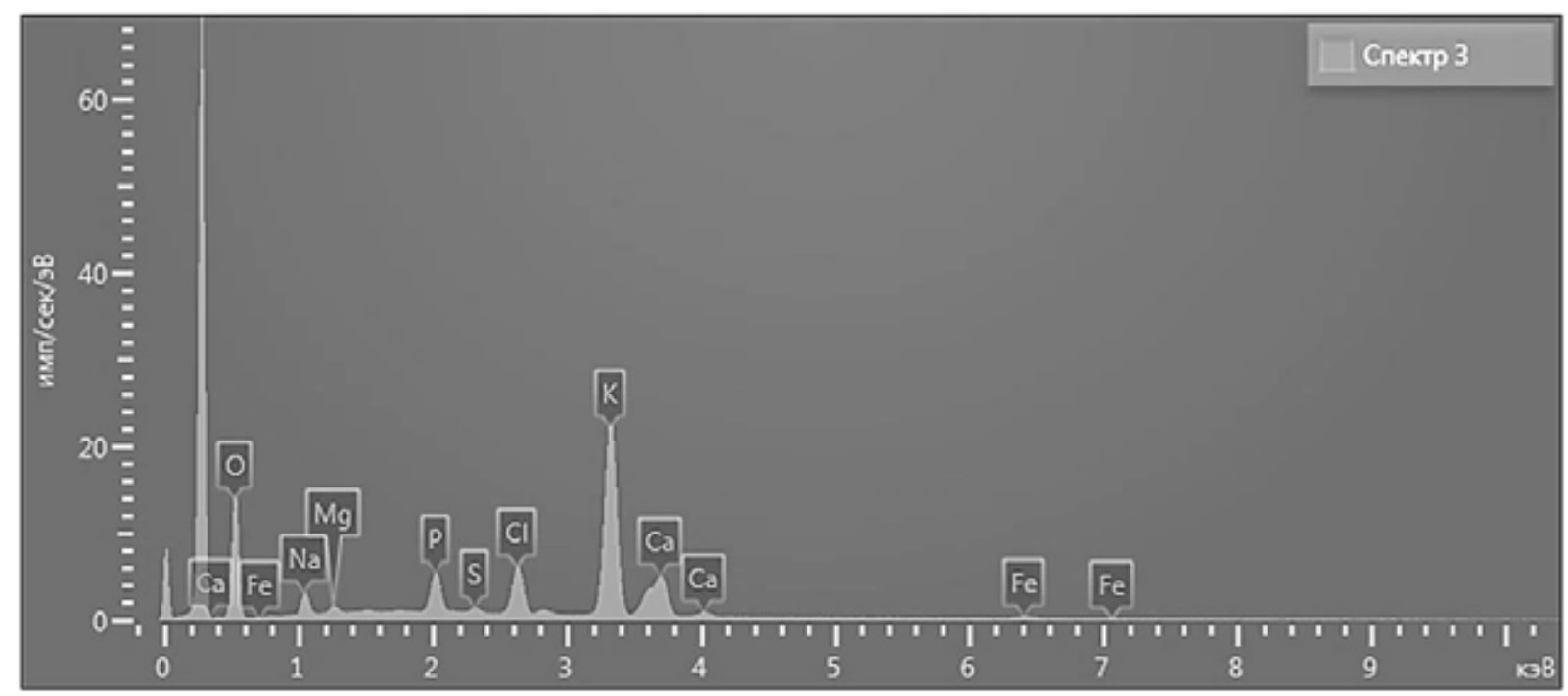

Рис. 1. Результати хімічного складу морквяного порошку

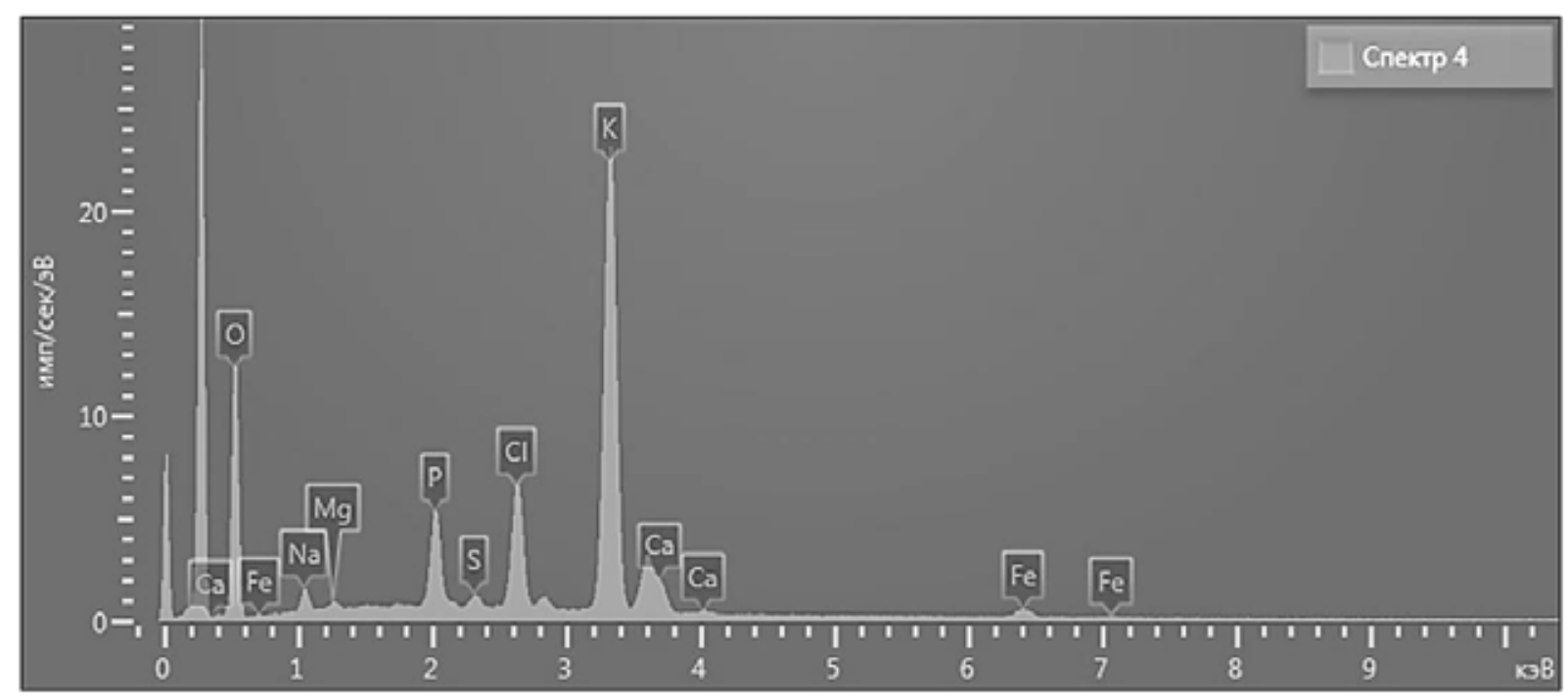

Рис. 2. Результати хімічного складу порошку зі шкірок моркви

вирощування якої не використовуються синтетичні добрива.

Було виготовлено два експериментальні зразки на основі молока А2. Визначення генотипу зразків молока здійснювали за допомогою молекулярно-біологічного аналізу розпізнавання алелей методом полімеразно ланцюгової реакції (ПЛР) у реальному часі [20].

У зразок № 1 введено 10\% морквяного порошку (з основної частини коренеплоду), у зразок № $2-10 \%$ порошку із морквяних шкірок. Кількість доданого порошку було встановлено за рахунок серії попередньо проведених лабораторних досліджень, основним критерієм у яких було досягнення гарних органолептичних показників. За контроль використовували пряжене молоко. Зразки виготовлялися за технологічною схемою, представленою на рис. 3.
У дослідженні було встановлено, що морквяні порошки мають високу гідрофільність і добре відновлюються у рідині. Присутність крупних частинок (мезги) у молоці негативно впливала на органолептичні показники готового продукту, тому виникла необхідність їх видалення із молока шляхом фільтрування. Важливим завданням під час фільтрування було видалення лише крупної мезги, щоб максимально зберегти склад і фізико-хімічні властивості збагаченого молока. Як фільтрувальні перегородки використовували фільтри для цідилки молока FARMA (Нідерланди) діаметром 95 мм.

Органолептична оцінка показала, що додавання порошку не мало негативного впливу на консистенцію молока, оскільки крупна мезга видалялася шляхом фільтрування. Консистенція збагаченого молока не відрізнялася від консистенції 


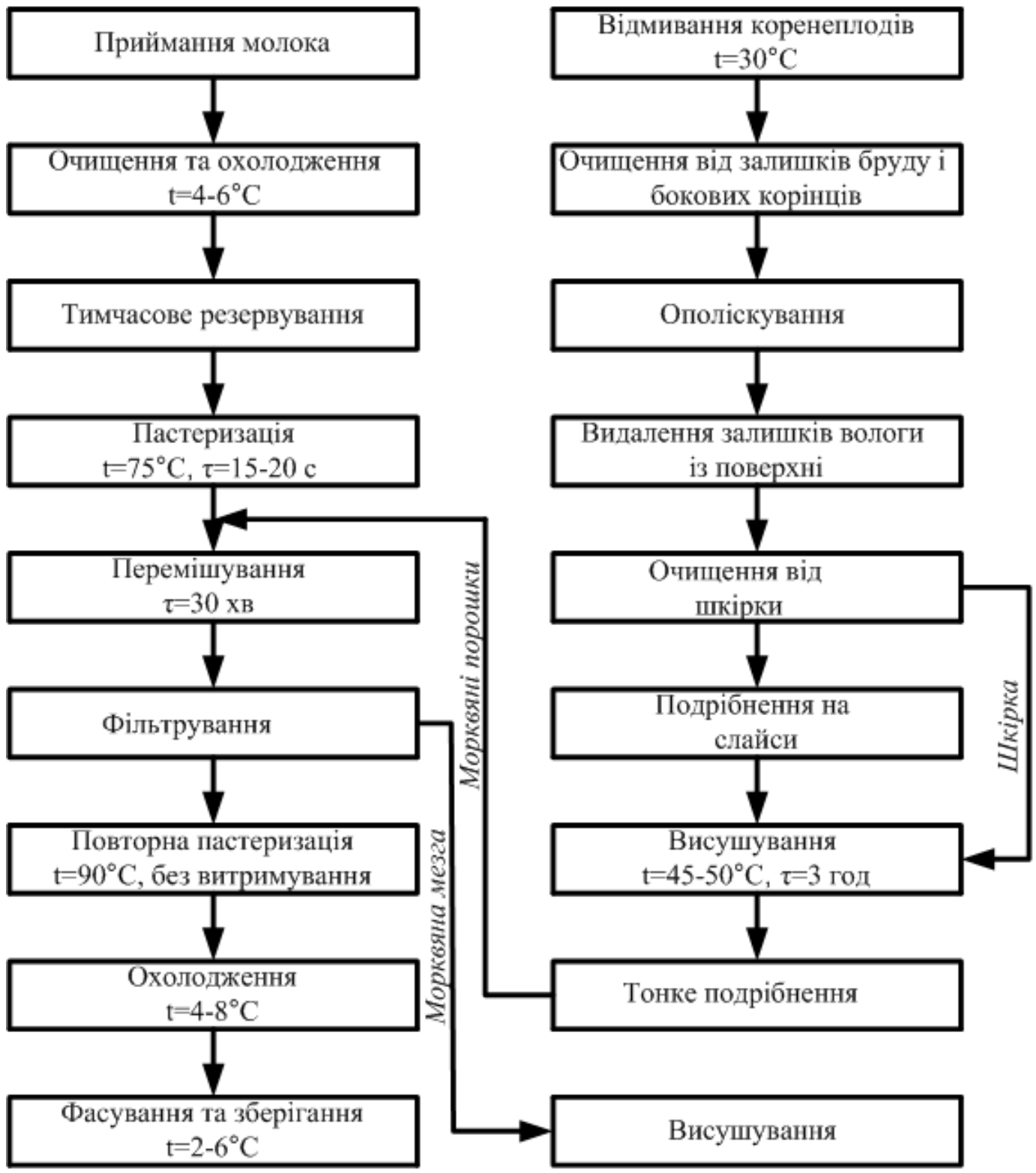

Рис. 3. Технологічна схема виготовлення збагаченого молока

пряженого, яке було використано як контрольний зразок. Результати повної органолептичної оцінки всіх зразків представлено на рис. 4.

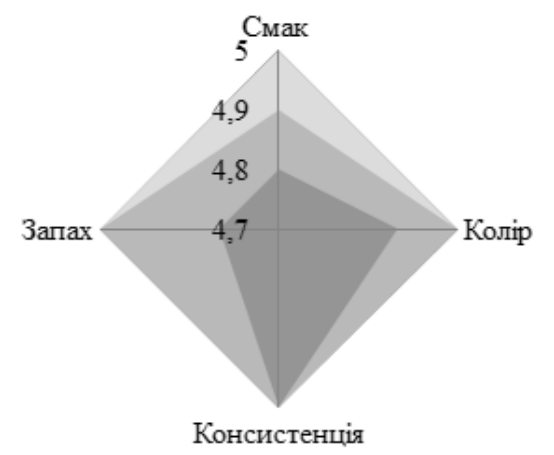

Рис. 4. Результати органолептичної оцінки

\begin{tabular}{l} 
готового продукту \\
\hline
\end{tabular}

Контроль

-Зразок №1

- Зразок №2
Зразок № 1 мав характерний для пастеризованого молока запах, приємний кремовий колір і легкий присмак моркви. У зразку № 2 відчувався помітний овочевий присмак і запах, колір зразка мав бруднуватий відтінок. Забарвлення готових продуктів свідчить про перехід каротиноїдів та інших речовин у молоко внаслідок дифузії.

Таким чином, молоко, збагачене морквяним порошком, мало високі споживні характеристики та майже не поступалося за якістю пряженому молоку.

Для аналізу здатності молока до зберігання було досліджено титровану кислотність зразків після 72 годин зберігання. Зразки зберігалися у скляних стерилізованих банках за температури $4^{\circ} \mathrm{C}$ у побутовому холодильнику. Результати представлено у таблиці 1. 
Таблиця 1

Титрована кислотність дослідних зразків, ${ }^{\circ} \mathrm{T}$

\begin{tabular}{|l|c|c|}
\hline Назва зразка & $\begin{array}{c}\text { Максимально } \\
\text { допустиме значення } \\
\text { (ДСТУ 2661:2010) }\end{array}$ & $\begin{array}{c}\text { Результати } \\
\text { експерименту }\end{array}$ \\
\cline { 1 - 1 } Контроль & \multirow{2}{*}{21} & 18 \\
\cline { 1 - 1 } Зразок № 1 & & 20 \\
\hline Зразок № 2 & & 25 \\
\hline
\end{tabular}

Зразок № 1, виготовлений на основі морквяного порошку з основної частини коренеплоду, відповідав нормованому значенню. Зразок із додаванням порошку зі шкірок моркви мав кислотність, на $4^{\circ} \mathrm{T}$ вищу за максимально допустиму. Очевидно, на поверхні шкірки залишається частина мікроорганізмів, які активуються у молоці та спричиняють його скисання. Таким чином, використовувати порошки з морквяних шкірок для збагачення молока не рекомендується. У разі їх використання як харчових добавок варто застосовувати такі режими термічної обробки, що дозволять знищити мікроорганізми. Порошки зі шкірок можна додавати у хлібобулочні вироби для підвищення вмісту харчових волокон і покращення мінерального складу, оскільки випікання здійснюється за високих температур.

Висновки із зазначених проблем i перспективи подальших досліджень у поданому напрямі. Результати проведених досліджень показали, що:

- у порошках із основної частини коренеплодів моркви міститься: 27,1\% К; 6,97\% Са; 5,09\% $\mathrm{Cl} ; 3,82 \% \mathrm{P} ; 3,3 \% \mathrm{Na} ; 1,07 \% \mathrm{Fe} ; 0,75 \% \mathrm{Mg}$ i $0,47 \%$ $\mathrm{S}$. Це доводить доцільність їх застосування для збагачення молока мінеральними речовинами;

- розроблено технологію збагачення молока морквяними порошками, яка може бути безвідходною за умови висушування та подальшого використання як джерела харчових волокон. Розробка технології використання висушеної морквяної мезги $\epsilon$ перспективою наших подальших досліджень;

- додавання морквяного порошку до молока позитивно впливає на його органолептичні властивості. Збагачене молоко А2 має характерну для пряженого молока консистенцію, приємний запах, кремовий колір і легкий присмак моркви;

- збагачене молоко А2 має високу здатність до зберігання, це підтверджується тим, що титрована кислотність молока, збагаченого морквяним порошком із основної частини коренеплодів, відповідає нормативним значенням. Процеси псування молока, виготовленого на основі морквяних шкірок, пришвидшуються, тому морквяні шкірки не рекомендується використовувати для збагачення молока.

\section{СПИСОК ВИКОРИСТАНИХ ДЖЕРЕЛ}

1. Про затвердження норм та Порядку організації харчування у закладах освіти та дитячих закладах оздоровлення та відпочинку : Постанова № 305 від 24 березня 2021 р. / Кабінет Міністрів України. https://zakon.rada.gov. ua/laws/show/305-2021-\%D0\%BF\#Text. (дата звернення: 23.11.2021)

2. Clare M. Hasler. Functional Foods: Benefits, Concerns and Challenges - A Position Paper from the American Council on Science and Health. The Journal of Nutrition. 2002 Vol. 132. Iss. 12. P. 3772-3781. https://doi.org/10.1093/ jn/132.12.3772

3. Fa-Ming Chen, Xiaohua Liu. Advancing biomaterials of human origin for tissue engineering. Progress in Polymer Science. 2015. Vol. 53. P. 86-168. doi: 10.1016/j.progpolymsci.2015.02.004.

4. Jung Tae-Hwan, Hwang Hyo-Jeong, Yun Sung-Seob, Lee Won-Jae, Kim Jin-Wook, Ahn Ji-Yun, Jeon Woo-Min, Han Kyoung-Sik. Hypoallergenic and Physicochemical Properties of the A2 $\beta$-Casein Fractionof Goat Milk. Korean Journal for Food Science of Animal Resources. 2017. Vol. 37 (6). P. 940-947. doi:10.5851/kosfa.2017.37.6.940.

5. Kamiński S., Cieslińska A., Kostyra E. Polymorphism of bovine beta-casein and its potential effect on human health. Journal of Applied Genetics. 2007. Vol. 48:1. P. 89-98. DOI: 10.1007/BF03195213.

6. Бирюкова 3.А., Коваленко Л.М., Пантелеева О.Г. Сохранность витаминов, микроэлементов и кальция при производстве и хранении обогащенных стерилизованных молочных продуктов. Молочное дело. 2007. № 8. C. $18-19$.

7. Фіалковська Л.В. Дослідження і розробка технології збагаченого молока. Техніка, енергетика, транспорт АПК. 2018. № 4. Вип. 103. С. 51-56.

8. Способ получения обогащенного пастеризованного молока: пат. Росія : МПК А23С 3/02. А23С 9/152. № 2290818 ; заявл. 10.02.06; опубл. 10.01.07, Бюл. № 1.5 с

9. Пономарев Е.Е., Козлов В.Н., Пономарева Л.Ф. Технология производства ультрапастеризованного молоко, обогащенного йодом. Технічні науки: стан, досягнення і перспективи розвитку м'ясної, олієжирової та молочної галузей : мат. II міжнар. наук.-техн. конф., 21 березня 2013 р. м. Київ: НУХТ, 2013. С. 74-76.

10. Способ получения лечебного продукта на основе молока : пат. Росія : МПК А 23 С 9/13. № 2079222 ; заявл. 30.11.94; опубл. 10.05.97.

11. Активация гидрофильных свойств каротиноидов растительного сырья : монография / В.В. Погарская, Р.Ю. Павлюк, А.И. Черевко, В.А. Павлюк, Н.Ф. Максимова. Харьков, 2013. 345 с.

12. Ладика Л.М., Машкін М.І., Могутова В.Ф., Богомолов О.В., Денисенко С.А. Розробка технології пастеризованого молока з додаванням ваніліну і $\beta$-каратину. Вісник Харківського національного технічного університету сільського господарства ім. Петра Василенка. 2016. Вип. 179. С. 90-100. 
13. Українцева Ю.С., Гросу Є.І. Білкова паста для дитячого харчування з подовженим терміном зберігання. Збірник наукових праць молодих учених, аспірантів та студентів. Одеса : ОНАХТ, 2014. С. 194-196

14. Combet E., Buckton C. Micronutrient deficiencies, vitamin pills and nutritional supplements. Medicine. 2019. Vol. 47 (3). P. 145-151.

15. Pavlyuk R., Pogarska V., Radchenko L., Tauber R.D., Timofeyeva N. Deep Processing of Carotene-Containing Vegetables and Obtaining Nanofood With the Use of Equipment of New Generation. Eastern-European Journal of Enterprise Technologies. 2016. Vol. 4, № 11(82). P. 36-43. doi:10.15587/1729-4061.2016.76232.

16. Perrin F. et al. Carotenoid gene expression explains the difference of carotenoid accumulation in carrot root tissues. Planta. 2017. Vol. 245. P. 737-747. DOI:10.1007/s00425-016-2637-9.

17. Снєжкін Ю.Ф., Петрова Ж.О., Пазюк В.М. Гідротермічна обробка функціональної сировини. Наукові nрaui. 2012. Вип. 41 (1). С. 13-17.

18. Elsner P. Oxidants and Antioxidants in Cutaneous Biology. J Thiele Current Problems in Dermatology. London, 2001. Vol. 29.

19. Про затвердження Правил додавання вітамінів, мінеральних речовин та деяких інших речовин до харчових продуктів: Наказ від 16.07.2020 р. № 1613 / Міністерство охорони здоров’я України. URL: https://zakon.rada. gov.ua/laws/show/z0891-20\#Text.

20. ТУ У 01.4-04718013-001:2020. Молоко А2 незбиране. Технічні умови. Суми, 2020. 23 с.

\section{REFERENCES}

1. Pro zatverdzhennya norm ta Poryadku orhanizatsiyi kharchuvannya u zakladakh osvity ta dytyachykh zakladakh ozdorovlennya ta vidpochynku: Postanova № 305 [On approval of norms and the Procedure for the organization of food in educational institutions and children’s health and recreation facilities: Resolution № 305 of March 24, 2021, Cabinet of Ministers of Ukraine.] Retrieved from https://zakon.rada.gov.ua/laws/show/305-2021-\%D0\%BF\#Text. (appeal date: 23.11.2021) [in Ukrainian].

2. Clare M. Hasler. (2002). Functional Foods: Benefits, Concerns and Challenges - A Position Paper from the American Council on Science and Health. The Journal of Nutrition.132.12. (pp. 3772-3781). https://doi.org/10.1093/ jn/132.12.3772 [in English].

3. Fa Ming, Chen, Xiaohua, Liu. (2015). Advancing biomaterials of human origin for tissue engineering. Progress in Polymer Science. 53. (pp. 86-168). doi: 10.1016/j.progpolymsci.2015.02.004 [in English].

4. Jung, Tae-Hwan et al. (2017). Hypoallergenic and Physicochemical Properties of the A2 $\beta$-Casein Fractionof Goat Milk. Korean Journal for Food Science of Animal Resources. 37 (6). (pp. 940-947). doi:10.5851/kosfa.2017.37.6.940 [in English].

5. Kamiński, S., Cieslińska, A., Kostyra, E. (2007). Polymorphism of bovine beta-casein and its potential effect on human health. Journal of Applied Genetics. 48:1. (pp. 89-98). DOI: 10.1007/BF03195213 [in English].

6. Biryukova, Z.A., Kovalenko, L.M., Panteleeva, O.G. (2007). Sokhrannost' vitaminov, mikroelementov i kal'tsiya pri proizvodstve i khranenii obogashchennykh sterilizovannykh molochnykh produktov [Preservation of vitamins, trace elements and calcium during the production and storage of fortified sterilized dairy products]. Molochnoye delo - Dairy business. 8. (pp. 18-19) [in Russian].

7. Fialkovs'ka, L.V. (2018). Doslidzhennya i rozrobka tekhnolohiyi zbahachenoho moloka. [Research and development of enriched milk technology]. Tekhnika, enerhetyka, transport APK-Machinery, energy, transport of agroindustrial complex 4.103. (pp. 51-56) [in Ukrainian].

8. Sposob polucheniya obogashchennogo pasterizovannogo moloka: pat. Rosíya : MPK A23C 3/02. A23C 9/152. № 2290818 [Method for producing enriched pasteurized milk zayavl]. 10.02.06; opubl. 10.01.07, Byul. № 1. P. 5 [in Russian].

9. Ponomarev, E.E., Kozlov, V.N., Ponomareva, L.F. (2013). Tekhnolohyya proyzvodstva ul'trapasteryzovannoho moloko, obohashchennoho yodom. [Research and development of enriched milk technology] Mat. II mizhnar. nauk.tekhn. Konf. "Tekhnichni nauky: stan, dosyahnennya i perspektyvy rozvytku m'yasnoyi, oliyezhyrovoyi ta molochnoyi haluzey" - Machinery, energy, transport of agro-industrial complex, Kyyiv: NUKHT (pp. 74-76) [in Russian].

10. Sposob polucheniya lechebnogo produkta na osnove moloka : pat. Rosíya : MPK A 23 S 9/13. № 2079222 [Method for obtaining a medicinal product based on milk] zayavl. 30.11.94; opubl. 10.05.97. [in Russian].

11. Pogarskaya, V.V., Pavlyuk, R.Yu., Cherevko, A.I., Pavlyuk, V.A., Maksimova, N.F. (2013). Aktivatsiya gidrofil'nykh svoystv karotinoidov rastitel'nogo syr'ya : monografiya [Activation of hydrophilic properties of plant raw material carotenoids: monograph] Kharkív. P. 345. [in Russian].

12. Ladyka, L.M., Mashkin, M.I., Mohutova, V.F., Bohomolov, O.V., Denysenko, S.A. (2016). Rozrobka tekhnolohiyi pasteryzovanoho moloka $\mathrm{z}$ dodavannyam vanilinu i b-karatynu. [Development of pasteurized milk technology with the addition of vanillin and $\beta$-carotene] Visnyk Kharkivs'koho natsional'noho tekhnichnoho universytetu sil's'koho hospodarstva im. Petra Vasylenka - Bulletin of the Petro Vasylenko Kharkiv National Technical University of Agriculture 179. (pp. 90-100). [in Ukrainian].

13. Ukrayintseva, Yu.S., Hrosu, Ye.I. (2014). Bilkova pasta dlya dytyachoho kharchuvannya z podovzhenym terminom zberihannya [Protein paste for baby food with extended shelf life.]. Zbirnyk naukovykh prats' molodykh uchenykh, aspirantiv ta studentiv - Collection of scientific works of young scientists, graduate students and students. Odesa: ONAKHT (pp. 194-196). [in Ukrainian]. 
14. Combet, E, Buckton, C. (2019). Micronutrient deficiencies, vitamin pills and nutritional supplements. Medicine. 47 (3). (pp.145-151). [in English].

15. Pavlyuk, R., Pogarska, V., Radchenko, L., Tauber, R. D., Timofeyeva, N. (2016). Deep Processing of CaroteneContaining Vegetables and Obtaining Nanofood With the Use of Equipment of New Generation. Eastern-European Journal of Enterprise Technologies. 4.11 (82). (pp. 36-43). doi:10.15587/1729-4061.2016.76232. [in English].

16. Perrin F. et al. (2017). Carotenoid gene expression explains the difference of carotenoid accumulation in carrot root tissues. Planta. 245. (pp. 737-747). DOI:10.1007/s00425-016-2637-9. [in English].

17. Snyezhkin, Yu.F., Petrova, Zh.O., Pazyuk, V.M. (2012). Hidrotermichna obrobka funktsional'noyi syrovyny [Hydrothermal treatment of functional raw materials]. Naukovi pratsi - Scientific works. 41 (1). (pp. 13-17). [in Ukrainian].

18. Elsner P. (2001). Oxidants and Antioxidants in Cutaneous Biology. J Thiele Current Problems in Dermatology. London, 29. [in English].

21. Pro zatverdzhennya Pravyl dodavannya vitaminiv, mineral'nykh rechovyn ta deyakykh inshykh rechovyn do kharchovykh produktiv: Nakaz vid 16.07.2020 r. № 1613 / Ministerstvo okhorony zdorovya Ukrayiny. URL: https:// zakon.rada.gov.ua/laws/show/z0891-20\#Text. [in Ukrainian].

19. TU U 01.4-04718013-001:2020. Moloko A2 nezbyrane [A2 whole milk]. Tekhnichni umovy. Specifications. Sumy, 2020. P. 23. [in Ukrainian].

M. Samilyk, PhD, Associate Professor (Sumy National Agrarian University); R. Tsyrulyk (Sumy National Agrarian University). The use of carrot powders to enrich milk with mineral elements.

Abstract. Milk is the main source of protein and a must-have in the daily diet of children. It is recommended to consume milk with added vitamins and minerals. That is why milk fortification is a topical issue. The purpose of the study is to substantiate the expediency of using carrot powders for enriching milk with minerals. Milk quality indicators were determined according to standard methods: organoleptic assessment was carried out according to DSTU 2661: 2010, titrated acidity was determined according to DSTU 8550: 2015. Chemical analysis of powders was carried out by electron microscopy using SEM and EDS detectors. Powders were made from the root crops of Shantane carrots and their skins under laboratory conditions and a technology for enriching A2 milk with them was developed. Analysis of the chemical composition showed that carrot powders from the main part of root crops contain K (27.1\%), Ca (6.97\%), Cl (5.09\%), P (3.82\%), Na (3.3\%), Fe (1.07\%), Mg (0.75\%) and S (0.47\%). It was found that the addition of carrot root vegetable powder in the amount of $10 \%$ had a positive effect on the organoleptic properties of milk without reducing its storage capacity. The fortified milk had a characteristic pasteurized smell, a pleasant creamy color, and a slight carrot flavor. The consistency of the developed product corresponded to that of pasteurized milk. It was found that some mineral substances in carrot peel powders contain more than in the main part of the root crop: $K-$ by $4.28 \%, F e-$ by $0.73 \%, P-$ by $0.45 \%, S-b y 0.12 \%$. But the addition of such powders to milk significantly reduces its quality indicators and leads to rapid deterioration of the product. The sample with carrot waste powder had a dirty tint and a characteristic vegetable taste and aroma. The acidity of milk with the addition of powder from carrot skins exceeded the standard value by $4^{\circ} \mathrm{T}$. This technology can be waste-free, in the case of drying the carrot pulp obtained after filtering milk and using it as a food additive. The development of a technology for using dried carrot pulp is a prospect for further research.

Key words: fortified milk A2, carrot powder, carrot peels, chemical composition, mineral substances, waste-free technology. 